\title{
Aspects of mating behavior and antennal sensilla in Anomala inconstans Burmeister, 1844 (Coleoptera: Scarabaeidae: Rutelinae)
}

\author{
Sérgio Roberto Rodrigues ${ }^{1 *} \mathbb{\oplus}^{-}$, Juares Fuhrmann ${ }^{2}$ \& Ricardo Aparecido Amaro ${ }^{I}$ \\ ${ }^{1}$ Universidade Estadual de Mato Grosso do Sul, Rodovia MS, 306, km 6,4, Cassilândia, MS, Brasil \\ ${ }^{2}$ Universidade de São Paulo, Museu de Zoologia, São Paulo, SP, Brasil \\ *Corresponding author: Sérgio Roberto Rodrigues,e-mail: sergio@uems.br
}

RODRIGUES, S. R., FUHRMANN, J., AMARO, R. A. Aspects of mating behavior and antennal sensilla in Anomala inconstans Burmeister, 1844 (Coleoptera: Scarabaeidae: Rutelinae). Biota Neotropica. 19(3): e20180664. http://dx.doi.org/10.1590/1676-0611-BN-2018-0664

\begin{abstract}
When suitable, adults of Scarabaeidae usually form swarms to find food and breeding sites. The steps of mating behavior can be mediated by chemical communication, and antennal sensilla are released volatiles detection structures, as sexual pheromones. In present work the mating behavior and the antennal sensilla of Anomala inconstans Burmeister, 1844 are described. The study was conducted at the Universidade Estadual de Mato Grosso do Sul, Cassilândia, Brazil from March 2015 to December 2017. Adults were collected through a light trap and taken to the laboratory for studies. Field and laboratory observations provided data for the description of the steps of mating behavior. Adults swarms were registered from September to November 2015 at 05:30 pm to 00:00 am. Females display a calling behavior from $05: 25 \mathrm{pm}$ to $08: 00 \mathrm{pm}$, in which they rub their posterior legs against their abdomen, and after a few minutes males are able to locate them. In laboratory, the mating process lasted 20.4 minutes on average, and the possibility of chemical communication between adults was here discussed. The antennae of the species have trichoid, chaetica, placoid types I, II and III, and coeloconic types I and II sensilla. Placoid sensilla are the most abundant and females have more sensilla than males.
\end{abstract}

Keywords: Anomalini, chemical communication, chemical receptors, Neotropical, Scarabaeoidea.

\section{Aspectos do comportamento de cópula e sensilos antenais em Anomala inconstans Burmeister, 1844 (Coleoptera: Scarabaeidae: Rutelinae)}

Resumo: Em condições adequadas os adultos de Scarabaeidae geralmente realizam revoadas em busca de alimento e áreas de reprodução. As etapas relacionadas ao comportamento de cópula podem ser intermediadas por comunicação química, e os sensilos antenais são as estruturas que detectam os voláteis como os feromônios sexuais. No presente trabalho o comportamento de cópula e os sensilos antenais de Anomala inconstans Burmeister, 1844 são descritos. Os estudos foram conduzidos na Universidade Estadual de Mato Grosso do Sul, Cassilândia, de março de 2015 a dezembro de 2017. Adultos foram coletados com armadilha luminosa e conduzidos para laboratório para estudos. Observações de campo e de laboratório permitiram a descrição das etapas do comportamento de cópula. Os adultos revoaram de setembro a novembro de 2015 das 17:30h as 24:00h. As fêmeas apresentam o comportamento de chamamento das 17:25h as 20:00h, no qual atrita o terceiro par de pernas no abdome e, transcorridos alguns minutos, os machos as localizam. Em laboratório a cópula durou em média 20,4 minutos, sendo verificada a possibilidade de comunicação química entre os adultos. Nas antenas foram encontrados sensilos tricódios, chaéticos, placódios dos tipos I, II e III, e coelocônicos tipo I e II. Os sensilos placódios são os mais abundantes, e as fêmeas possuem mais sensilos do que os machos.

Palavras-chave: Anomalini, comunicação química, receptores químicos, Neotropical, Scarabaeoidea. 


\section{Introduction}

Phytophagous scarab beetles (Coleoptera: Scarabaeidae) in Neotropical region usually swarm during the hot and humid period of the year, when they can be observed feeding on leaves, flowers and fruit of several plant species (Oliveira \& Ávila 2011, Gottsberger et al. 2012, Martínez et al. 2013, Moore \& Jameson 2013, Ferreira et al. 2016, Rodrigues et al. 2016). The different plant species used for feeding are important breeding sites for Scarabaeidae (Morón 1996, Maia \& Schlindwein 2006, Rodrigues et al. 2017).

The mating process of Scarabaeidae can be subdivided into steps. Initially, adults land on plants after swarming, attracted by plant volatile chemicals (Stensmyr et al. 2001, Ruther 2004). Then, females exhibit a calling behavior and release a sexual pheromone to attract males (Tada \& Leal 1997, Facundo et al. 1999, Robbins et al. 2009). At that moment, males can locate females and initiate chemical recognition processes, after what females select males to mate (Fávila 1988).

Adult Scarabaeidae locate and recognize plant volatiles and female pheromones through antennal sensilla, which are quite diverse (Larsson et al. 2001, Ochieng et al. 2002, Romero-López et al. 2004, 2010, Romero-López 2016).

Some species of Scarabaeidae might be regarded as important crop pests in Brazil (Oliveira et al. 2007, Santos \& Ávila 2007, Coutinho et al. 2011). Among such species, Anomala inconstans Burmeister, 1844 (Rutelinae, Anomalini) has been observed developing in corn (Zea mays L.) (Poaceae) crops (Rodrigues et al. 2011). In Colombia, larvae of this species were reported damaging roots of pasture, cassava (Manihot sp.) (Euphorbiaceae), coffee (Coffea sp.) (Rubiaceae) and wild plants (Pardo-Locarno et al. 2005). Immature $A$. inconstans was described by Ramírez-Salinas et al. (2004).

Present study proposes to describe the antennal sensilla and mating behavior of $A$. inconstans based in material collected in pasture areas in Cassilândia, Mato Grosso do Sul, Brazil.

\section{Material and Methods}

The study was conducted at the Universidade Estadual de Mato Grosso do Sul (UEMS), Campus of Cassilândia. Adults of $A$. inconstans were collected using a light trap model "Luiz de Queiroz" from March 2015 to December 2017. The trap was installed in a pasture area (Brachiaria decumbens Stapf cv. Basilisk, Poaceae), was turned on daily at 05:00 pm and turned off at 6:00 am of the next day. Insects were collected every 60 minutes (methodology by Rodrigues et al. 2014).

Data of average temperature $\left({ }^{\circ} \mathrm{C}\right)$, rainfall $(\mathrm{mm})$ and solar radiation $\left(\mathrm{KJ} / \mathrm{m}^{2}\right)$ in Cassilândia were obtained from the website of the Instituto Nacional de Meteorologia (INMET: http://www.inmet.gov.br/portal/).

Observations of the mating behavior were conducted from October to November of 2015 and 2016. Adults collected were sexed and individually placed into $1,000 \mathrm{ml}$ plastic containers, containing about 666 $\mathrm{ml}$ of soil collected from pasture area and covered with voile fabric. The behavior of adults was observed during the evening, when they emerged from the soil. Males and females were brought together after they left the soil. Thirty-four couples were formed to allow mating behavior observations (methodology adapted from Rodrigues et al. 2014).
From September to November 2017, behavior observations were carried out in the UEMS pasture area with $B$. decumbens grass, from 05:00 to 08:00 pm. During this period, high temperatures and high humidity were observed in the studied region.

The study of antennal sensilla was based in antennal clubs of 10 dissected specimens. Images were taken by a scanning electron microscope (model JSM 5410) from the Laboratório de Microscopia Eletrônica of the Universidade Estadual Paulista, campus of Jaboticabal, São Paulo State. Sensilla terminology follows Keil (1999). Meinecke (1975) was used as an alternative sensilla terminology (in brackets) to easily term comparison.

The antennal lamellae were also mounted on slides for optical microscope observation. Antennal segments were formerly treated in a $10 \%$ potassium hydroxide solution at $80^{\circ} \mathrm{C}$ for 60 minutes. The pieces were then successively washed in distilled water, $70 \%$ ethanol, $80 \%$ ethanol, and $90 \%$ ethanol, respectively. After that, the material was cleared in xylene for 10 minutes. Finally, the lamellae were mounted on slides with Hoyer's solution (Johnson \& Triplehorn 2005) replacing the Canada Balsam as described by Romero-Lopez et al. (2004) and then observed under a Nikon microscope model E2000. The insects were deposited in the UEMS insects collection, campus of Cassilândia, MS.

\section{Results}

Mating behavior. Adults were collected using a light trap from September to November 2015. Fifty specimens were collected in September, 61 in October, and 9 in November. They were collected from 05:30 pm to 00:00 am (Figure 1). From 05:00 to 06:00 pm, brightness decreases from $10.76 \mathrm{KJ} / \mathrm{m}^{2}$ to $0.0 \mathrm{KJ} / \mathrm{m}^{2}$ (Figure 2) and beetles started to fly when it is dark. The highest number of adults was obtained from 06:00 to 07:00 pm where the average temperature was $26.4^{\circ} \mathrm{C}$ (Figure 2). From 07:00 pm onwards, was a decrease in the number of adults collected and after 11:00 pm they stopped appearing.

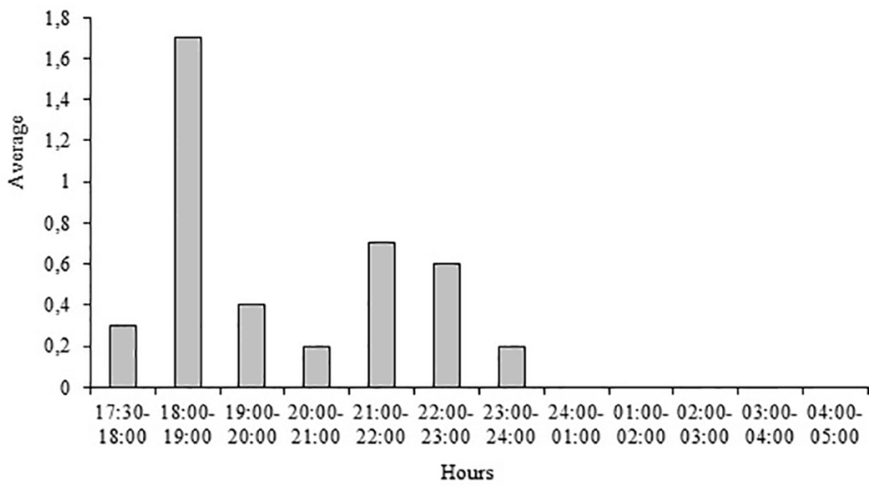

Figure 1. Adult Anomala inconstans, collected through a light trap. Data from September 29 to October 2, 2015. Cassilândia, MS, Brazil.

Laboratory observations showed that during the day, adult of $A$. inconstans remained under the soil. After dark, from 06:00 pm onward, adults initially project a small portion of their clypeus near soil surface and then leave the soil completely. 


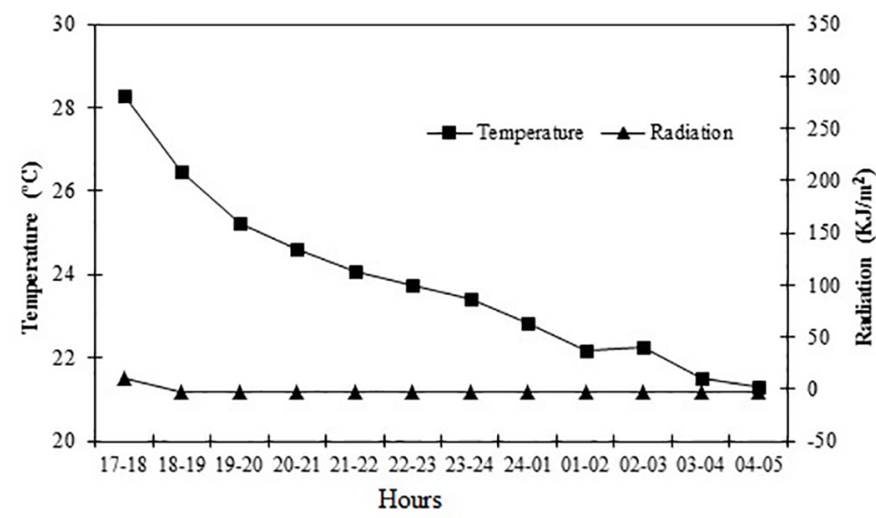

Figure 2. Average temperature $\left({ }^{\circ} \mathrm{C}\right)$ and radiation $\left(\mathrm{KJ} / \mathrm{m}^{2}\right)$, obtained from meteorological station (INMET).

Females actively walk or fly for $5.12 \pm 0.37$ (2-9) minutes after they leave the soil $(n=34)$, then they decrease their activity, stand still, and start rubbing their posterior legs against their abdomen $(n=10)$. Males walk or fly for $8.62 \pm 0.47$ (4-14) minutes after they leave the soil $(\mathrm{n}=34)$, and then stand still.

After adults decreased their activity, 34 couples were formed. Of the 34 couples formed, 26 did not mate, so only eight couples presented the steps related to mating behavior. On one occasion, the male approached the female, extroverted its aedeagus, but it was rejected by the female.

The eight formed couples, show several steps that resulted in mating (Figure 3). Initially, adults touched each other with their clypeus while their antennae kept moving and lamellae remained open. Then, males positioned themselves on top of females, extroverted their aedeagus, and began copulation.

Copulation lasted $20.4 \pm 0.86$ (17-25) minutes. After copulation, males remained over females for $27.62 \pm 2.97$ (20-45) seconds, after which they detached themselves from females and flew or walked on the soil. This last step lasted $120 \pm 9.93$ (95-180) seconds. Finally, free females buried themselves into soil. Apparently, chemical recognition occurred during the aforementioned process.

Adults were observed flying over pasture from 05:20 pm onwards. Females left the ground, flew and landed on shrubs in the pasture. Females flew between 20 and $120 \mathrm{~cm}$ high, after which they initiated their male calling activity $(n=23)$. The calling behavior was initiated through the rubbing of the metafemur and tibiae against their abdomen (Figure 4). Then it was observed that males detect females while flying, land near them, walk toward them, and immediately begin copulation. Copulation lasted $26.61 \pm 0.36(24-29)(n=23)$ minutes.

Antennal sensilla. Trichoid, chaetica, placoid and coeloconic sensilla were found on the lamellae. Chaetica sensilla are long and thin, and trichoid sensilla are short and thin (Figure 5A). These sensilla are observed on the outer surface of club, especially the trichoid ones.

Placoid sensilla (types I, II and III) and coeloconic sensilla (types I and II) are located on the inner surface of proximal lamella, on outer and inner surfaces of the middle lamella, and on the inner surface of distal lamella. On the outer surface of distal lamella there are placoid sensilla, but no coeloconic sensilla, which are found in the proximal half of inner surface (Figure 5B). Placoid sensilla occur in the various areas of the lamellae, however, basiconic sensilla occur in the anterior third of the lamellae (Figure 5C).

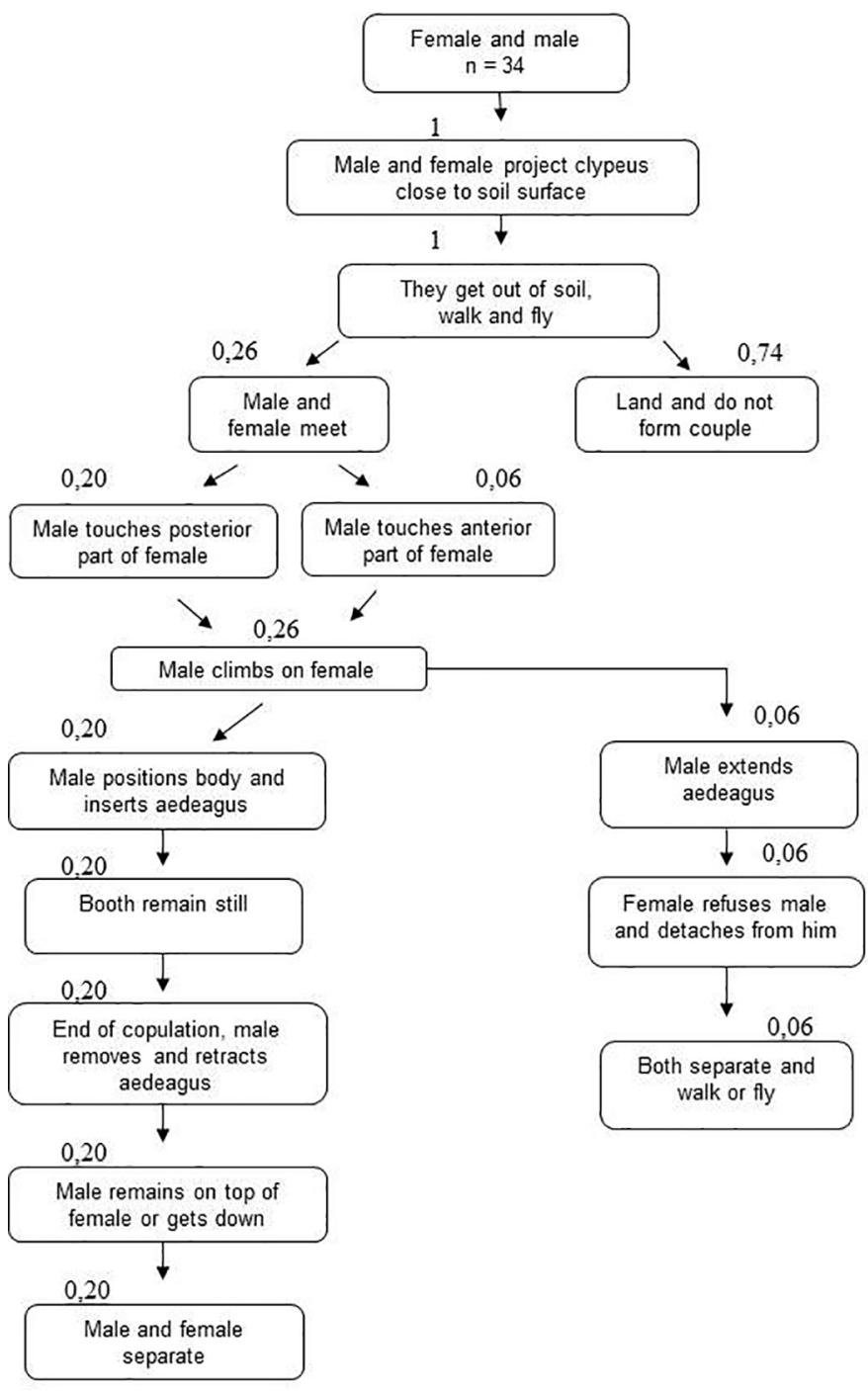

Figure 3. Ethogram of mating behavior of Anomala inconstans, in laboratory.

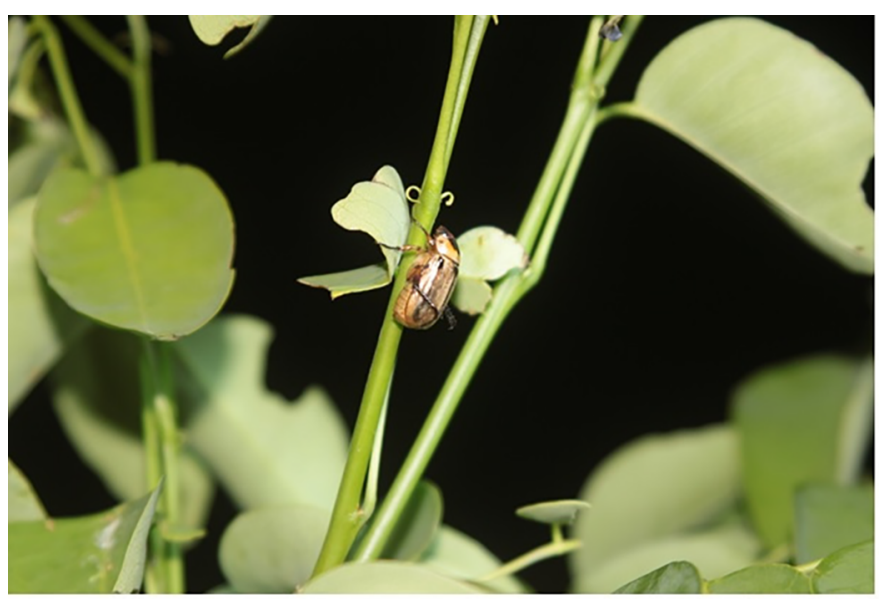

Figure 4. Calling behavior and potential release of sexual pheromone of female Anomala inconstans. 

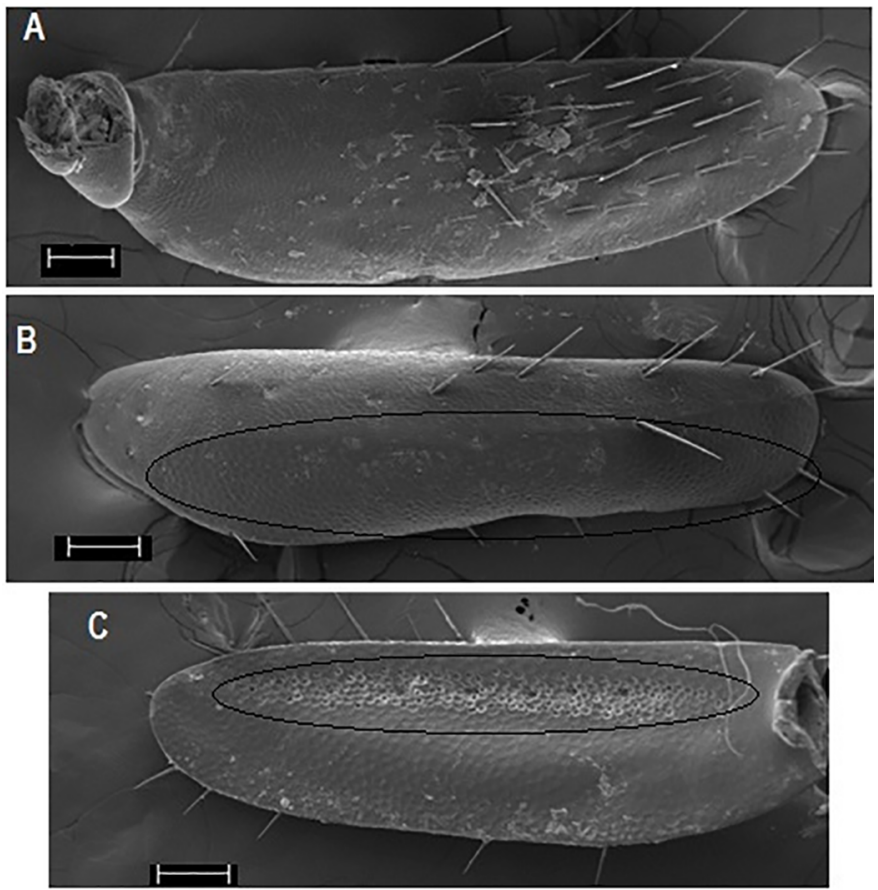

Figure 5. Antenna lamellae of Anomala inconstans. 5A) Trichoid and chaetica sensilla on outer area of proximal lamella. 5B) Placoid sensilla on outer distal lamella. 5C) Placoid and coeloconic sensilla on anterior third of lamella. Scale 100 micrometers.

Placoid sensilla types I, II and III were found. Type I placoid sensilla (H1 classification by Keil 1999) have an irregular shape with surface undulations and a mean diameter of $12.18 \mu \mathrm{m}$ (10-14) (Figure 6). Type II placoid sensilla (G1 classification of Keil 1999) have irregular shape, high edges, deeper undulations than type I, and a mean diameter of 6.45 $\mu \mathrm{m}$ (5.6-7.6) (Figure 6). Type III placoid sensilla (H3 classification of Keil 1999) have an irregular shape, flat surface, and a mean diameter of $12.6 \mu \mathrm{m}$ (11.2-16) (Figure 6).

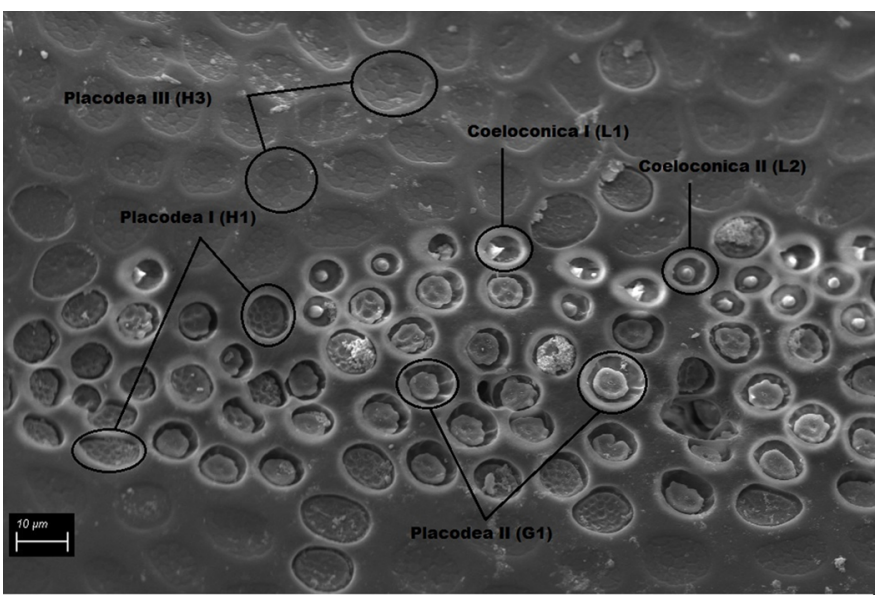

Figure 6. Placoid sensilla I, II and III, and coeloconic sensilla I and II on antennae of Anomala inconstans.
Coeloconic sensilla were classified as type I (L1 classification of Keil 1999) with acute apex, and type II (L2 classification of Keil 1999) with slightly dilated apex.

In females $(\mathrm{n}=10), 7784$ sensilla were quantified, 234 (3.04\%) of which are coeloconic and $7547(96.96 \%)$ placoid (Table 1). In males ( $\mathrm{n}=$ 10), 5741 sensilla were quantified, $176(3.06 \%)$ of which are coeloconic and 5565 (96.94\%) placoid (Table 1). Placoid sensilla are the most abundant in both sexes, and females have more sensilla than males.

\section{Discussion}

In present study, adult $A$. inconstans were collected from September to November. Other Scarabaeidae species also swarm for a short period of time in the field, as observed in Liogenys suturalis Blanchard, 1851 (Melolonthinae) (Santos \& Ávila 2009) and Geniates borelli Camerano, 1894 (Rutelinae) (Rodrigues et al. 2012).

Steps related to the mating behavior of $A$. inconstans are similar to those described by Rodrigues et al. (2014) for Anomala testaceipennis Burmeister, 1856. During the steps of the mating behavior, some female $A$. inconstans did not accept males for copulation, demonstrating male selection. This behavior was also observed in A. testaceipennis (Rodrigues et al. 2014), Cyclocephala verticalis Burmeister, 1847 (Dynastinae) (Barbosa \& Rodrigues 2016) and Leucothyreus albopilosus Ohaus, 1917 (Rutelinae) (Ferreira et al. 2016).

Observations made both in the laboratory and in the field demonstrated an intense activity of the antennae during several moments of copula. In laboratory, adults kept their antennae raised and made small movements with their lamellae open. In the field, females displayed a calling behavior and in few minutes a male would find them, and the couple would copulate.

Chaetica and trichoidea sensilla are found in outer side of club (inner side of proximal lamella, outer and inner sides of medial lamella, inner side of distal lamella). Keil (1999) describes chaetica and trichoidea sensilla as mechanoreceptors and contact chemoreceptors (gustative, mainly sensilla trichoidea). Sensilla chaetica are also found in other antennomeres.

Antennal lamellae of $A$. inconstans displayed placoid and coeloconic sensilla in the anterior third and placoid sensilla in the other areas. The sensilla types and distribution patterns in A. inconstans are similar to those characterized in other Rutelinae (Ågren 1985: Phyllopertha horticola (Linnaeus, 1758); Hansson et al. 1999: P. diversa Waterhouse, 1875; Kim \& Leal 2000: Popillia japonica Newman, 1841; Lu \& Wang 2009: Proagopertha lucidula (Faldermann, 1835); Mutis et al. 2014: Hylamorpha elegans (Burmeister, 1844); Leal \& Mochizuki 1993: Anomala cuprea (Hope, 1839); Yao et al. 2004 and Song et al. 2012: A. corpulenta Motschulsky, 1854). This pattern is formed by a lateral lamellar area with sensilla placodea without ditch (type III; Meinecke 1975: H3) and a central longitudinal groove (anteriorly positioned in A. inconstans) bearing sensilla placodea with ditch (type I; Meinecke 1975: H1, H2), flattened sensilla placodea (type II; Meinecke 1975: G1), acute sensilla coeloconica (type I; Meinecke 1975: S1) and rounded sensilla coeloconica (type II; Meinecke 1975: S2). 
Table 1. Sensilla on antennal lamellae of Anomala inconstans.

\begin{tabular}{|c|c|c|c|c|c|c|c|}
\hline \multirow{2}{*}{ Sensillum } & \multicolumn{2}{|c|}{ Proximal lamella } & \multicolumn{2}{|c|}{ Middle lamella } & \multicolumn{2}{|c|}{ Distal lamella } & \multirow{2}{*}{ Total } \\
\hline & outer & inner & outer & inner & outer & inner & \\
\hline & \multicolumn{7}{|c|}{ Female } \\
\hline Placoid & 0 & 1721 & 967 & 1650 & 1303 & 1906 & 7547 \\
\hline Total & 0 & 1804 & 998 & 1696 & 1303 & 1983 & 7784 \\
\hline Placoid & 0 & 1249 & 1226 & 1081 & 892 & 1117 & 5565 \\
\hline Total & 0 & 1289 & 1255 & 1102 & 892 & 1203 & 5741 \\
\hline
\end{tabular}

In Phyllopertha dispersa, all sensilla placodea and coeloconica are pheromone detecting structures, while sensilla of inner groove are both sexual pheromone and plant volatile detecting structure (Hansson et al. 1999).

Kim \& Leal (2000) suggested that the distribution sensilla pattern and sexual differences (sensilla abundance in male and female) are related with mate searching behavior intermediated by sexual pheromones in Rutelinae.

According Larsson et al. (2001) study of A. cuprea, the placoid sensilla of peripheral area of lamellae are responsible for detecting sexual pheromones, while sensilla in the central part detect plant volatiles and other odors. Otherwise, Sun et al. (2014) suggested that sensilla placodea was plant volatile main receptor and coeloconica as sexual attractant receptor to Holotrichia oblita (Faldermann, 1835) (Melolonthinae).

In concordance with above mentioned suggestions, Li et al. (1995) found that some Rutelinae (A. corpulenta, Popillia atrocoerulea Bates, 1888, P. quadriguttata (Fabricius, 1787)) are strong influenced by sexual attractant, while other phytophagous Scarabaeidae are more sensitive to food odorants or aggregative pheromones.

Sexual pheromones are not the only semiochemicals identified in scarab beetles. Some Dynastinae present aggregative attractants (Renou et al. 1998, Kim \& Leal 2000). To Anomala Samouelle, 1819, sexual pheromones were described, but not aggregative chemicals (c.f. Wang $\&$ Sun 2005).

Sexual pheromone producing tissue are seldom reported to scarab beetles. Kim \& Leal (1999) and Romero-Lopez et al. (2011) found melolonthine beetles (Phyllophaga obsoleta (Blanchard, 1850) and Holotrichia paralela (Motschulsky, 1854), respectively) bearing eversible glands in the terminalia that are extroverted during sexual calling and are related to pheromone production. In other melolonthine, Costelytra zealandica (White, 1846), females produce possible sexual attractants in their genital accessory glands in association with symbiotic microbes (Hoyt et al. 1971). Within Anomala, the pheromonal producer tissue is known to Anomala albopilosa albopilosa (Hope, 1839), in which sexual pheromone is produced in epithelial cells of the pygidium and last two ventrites, and these cells are linked with surface through puncture (Tada \& Leal, 1997). If the terminalia cells of other Anomala are considered as pheromone producer, as in A. albopilosa albopilosa, this could elucidate why attracted males touch female pygidium and abdomen with its antenna in matting process (Figure 3 ).

\section{Acknowledgments}

This work was supported by Fundação de Apoio ao Desenvolvimento do Ensino, Ciência e Tecnologia do Estado de Mato Grosso do Sul (FUNDECT) (Process n. 217/2016). To the Instituto Nacional de Ciência e Tecnologia (INCT) Semioquímicos na Agricultura (Fapesp 2014/50871-0) and CNPq (465511/2014-7) for the financial support. Juares Fuhrmann thanks Sônia A. Casari (Museu de Zoologia da Universidade de São Paulo) by suppervision.

\section{Author contributions}

Sérgio Roberto Rodrigues: Contribution to data collection; Contribution to data analysis and interpretation; Contribution to manuscript preparation; Contribution to critical revision, adding intellectual content.

Juares Fuhrmann: Contribution in the analysis and interpretation of data, also assisting in article revision, adding intellectual content.

Ricardo Aparecido Amaro: Contribution to data collection; Contribution to data analysis and interpretation; Contribution to manuscript preparation; Contribution to critical revision.

\section{Conflicts of interest}

The authors declare that they have no conflict of interest related to the publication of this manuscript.

\section{References}

$\AA ̊$ AREN, L. 1985. Architecture of a lamellicorn flagellum (Phyllopertha horticola, Scarabaeidae, Coleoptera, Insecta). J. Morphol. 186:85-94. https:// doi.org/10.1002/jmor. 1051860108

BARBOSA, C.A. \& RODRIGUES, S.R. 2016. Comportamento de cópula em Cyclocephala verticalis Burmeister (Coleoptera: Scarabaeidae). Entomobrasilis 9(3):158-162. http://dx.doi:10.12741/ebrasilis.v9i3.581

COUTINHO, G.V., RODRIGUES, S.R., CRUZ, E.C. \& ABOT, A.R. 2011. Bionomic data and larval density of Scarabaeidae (Pleurosticti) in sugarcane in the central region of Mato Grosso do Sul, Brazil. Rev. Bras. Entomol. 55(3):389-395.

FACUNDO, H.T., LINN, C.E., VILLANI, M.G. \& ROELOFS, W.L. 1999. Emergence, mating, and postmating behaviors of the oriental beetle (Coleoptera: Scarabaeidae). J. Insect Behav. 12(2):175-192.

FÁVILA, M.E. 1988. Comportamiento durante el período de maduración gonádica en un escarabajo rodador (Coleoptera: Scarabaeidae; Scarabaeinae). Folia Entomol. Mex. (76):55-64. 
FERREIRA, K.R., GOMES, E.S. \& RODRIGUES, S.R. 2016. Biological aspects and mating behavior of Leucothyreus albopilosus (Coleoptera: Scarabaeidae). Rev. Biol. Trop. 64(2):547-557. http://dx.doi.org/10.15517/ rbt.v64i2.19249

GOTTSBERGER, G., SILBERBAUER-GOTTSBERGER, I., SEYMOUR, R.S. \& DÖTTERL, S. 2012. Pollination ecology of Magnolia ovata may explain the overall large flower size of the genus. Flora. 207(2):107-118. https://doi.org/10.1016/j.flora.2011.11.003

HANSSON, B.S., LARSSON, M.C. \& LEAL, W.S. 1999. Green leaf volatiledetecting olfactory receptor neurones display very high sensitivity and specificity in a scarab beetle. Physiol. Entomol. 24:121-126. https://doi. org/10.1046/j.1365-3032.1999.00121.x

HOYT, C.P., OSBORNE, G.O. \& MULCOCK, A.P. 1971. Production of an insect sex attractant by symbiotic bacteria. Nature, 230:472-473. https:// doi.org/10.1038/230472a0

JOHNSON, N.F. \& TRIPLEHORN, C.A. 2005. Borror and DeLong's Introduction to the Study of Insects, 7th edition. Thomson Learning, Belmont.

KEIL, T.A. 1999. Chapter 1. Morphology and development of the peripheral olfactory organs, 6-44 p. In: Hansson, B. (ed). Insect olfaction. Springer, Berlin, $x+457 \mathrm{p}$.

KIM, J.K. \& LEAL, W.S. 1999. Eversible pheromone gland in a melolonthine beetle, Holotrichia parallela. J. Chem. Ecol. 25:825-833. https://doi. org/10.1023/A:1020896801562

KIM, J.Y. \& LEAL, W.S. 2000. Ultrastructure of pheromone-detecting sensillum placodeum of the Japanese beetle, Popillia japonica Newmann (Coleoptera: Scarabaeidae). Arthropod Struct. Dev. 29:121-128. https://doi.org/10.1016/ S1467-8039(00)00022-0

LARSSON, M.C., LEAL, W.S. \& HANSSON, B.S. 2001. Olfactory receptor neurons detecting plant odours and male volatiles in Anomala cuprea beetles (Coleoptera: Scarabaeidae). J. Insect Physiol. 47(9):1065-1076. https://doi. org/10.1016/S0022-1910(01)00087-7

LEAL, W.S. \& MOCHIZUKI, F. 1993. Sex pheromone reception in the scarab beetle Anomala cuprea. Naturwissenschaften 80:278-281.

LI, Z., LIU, C., WANG, Q. \& CUI, J. 1995. Effect of attractants on scarabs. Acta Agric. Boreali-Sinica 10:153-156.

LU, C.K. \& WANG, X.Q. 2009. Ultrastructure of olfactory sensilla on the antenna of Proagopertha lucidula (Coleoptera: Scarabaeidae). Acta Entomol. Sinica 52:39-45.

MAIA, A.C.D. \& SCHLINDWEIN, C. 2006. Caladium bicolor (Araceae) and Cyclocephala celata (Coleoptera, Dynastinae): a well-established pollination system in the Northern Atlantic rainforest of Pernambuco, Brazil. Plant Biol. 8:529-534. http://dx.doi.org/10.1055/s-2006-924045

MARTÍNEZ, L.C., PLATA-RUEDA, A., ZANUNCIO, J.C., SERRÃO, J.E. 2013. Leucothyreus femoratus (Coleoptera: Scarabaeidae): Feeding and behavioral activities as an oil palm defoliator. Fl. Entomol. 96(1):55-63. https://doi.org/10.1653/024.096.0107

MEINECKE, C.C. 1975. Riechsensillen und Systematik der Lamellicornia (Insecta, Coleoptera). Zoomorphologie 82:1-42.

MOORE, M.R. \& JAMESON, M.L. 2013. Floral associations of cyclocephaline scarab beetles. J. Insect Sci. 13:1-43. http://dx.doi.org/10.1673/031.013.10001

MORÓN, M.A. 1996. Coleoptera Melolonthidae asociados con las flores de Hibiscus rosa-sinensis L. (Malvaceae) en la región de Xalapa, Veracruz, México. G. It. Ent. 8(43):111-123.

MUTIS, A., PALMA, R., PARRA, L., ALVEAR, M., ISAACS, R., MORÓN, M. \& QUIROZ, A. 2014. Morphology and distribution of sensilla on the antennae of Hylamorpha elegans Burmeister (Coleoptera: Scarabaeidae). Neotrop. Entomol. 43:260-265. https://doi.org/10.1007/s13744-014-0208-y

OCHIENG, S.A., ROBBINS, P.S., ROELOFS, W.L. \& BAKER, T.C. 2002. Sex pheromone reception in the scarab beetle Phyllophaga anxia (Coleoptera: Scarabaeidae). Ann. Entomol. Soc. Am. 95(1):97-102.
OLIVEIRA, H.N. \& ÁVILA, C.J. 2011. Ocorrência de Cyclocephala forsteri em Acrocomia aculeata. Pesq. Agrop. Trop. 41(2):293-295.

OLIVEIRA, C.M., MORÓN, M.A. \& FRIZZAS, M.R. 2007. First record of Phyllophaga sp. aff. capillata (Coleoptera: Melolonthidae) as a soybean pest in the Brazilian "Cerrado". Fl. Entomol. 90(4):772-775.

PARDO-LOCARNO, L.C., MONTOYA-LERMA, J., BELLOTTI, A.C. \& SCHOONHOVEN, A.V. 2005. Structure and composition of the white grub complex (Coleoptera: Scarabaeidae) in agroecological systems of northern Cauca, Colombia. Fl. Entomol. 88(4):355-363.

RAMÍREZ-SALINAS, C., MORÓN, M.A., CASTRO-RAMÍREZ, A.E. 2004. Descripción de los estados inmaduros de tres especies de Anomala, Ancognatha y Lygirus (Coleoptera: Melolonthidae: Rutelinae y Dynastinae) con observaciones de su biología. Acta Zool. Mex. 20(3):67-82.

RENOU, M., TAUBAN, D. \& MORIN, J.P. 1998. Structure and function of antennal pore plate sensilla of Oryctes rhinoceros (L.) (Coleoptera: Dynastidae). J. Insect Morphol. Embryol. 27:116-122.

ROBBINS, P.S., NOJIMA, S., POLAVARAPU. S., KOPPENHÕFER, A.M., RODRIGUEZ-SAONA, C., HOLDERAFT, R.J., CONSOLIE, N.H., PECK, D.C. \& ROELOFS, W.L. 2009. Sex pheromone of the Scarab beetle Phyllophaga (Phytalus) georgiana (Horn). J. Chem. Ecol. 35:336-341.

RODRIGUES, S.R., CARMO, J.I., OLIVEIRA, V.S., FLORIANO, T.E. \& TAIRA, T.L. 2011. Ocorrência de larvas de Scarabaeidae fitófagos (Insecta: Coleoptera) em diferentes sistemas de sucessão de culturas. Pesq. Agrop. Trop. 41(1):87-93

RODRIGUES, S.R., BARBOSA, C.L., ABOT, A.R. \& IDE, S. 2012. Occurrence of adults and biological aspects of Geniates borelli Camerano (Coleoptera, Scarabaeidae, Rutelinae) in Aquidauana, Mato Grosso do Sul, Brazil. Rev. Bras. Entomol. 56(3):315-318.

RODRIGUES, S.R., GOMES, E.S. \& BENTO, J.M.S. 2014. Sexual dimorphism and mating behavior in Anomala testaceipennis. J. Insect Sc. $14: 1-5$.

RODRIGUES, S.R., MORÓN, M.A., GOMES, E.S. \& BENTO, J.M.S. 2016. Morphology of immature stages and mating behavior in Liogenys fusca (Blanchard) (Coleoptera, Melolonthidae, Melolonthinae). Rev. Bras. Entomol. 60:284-289.

RODRIGUES, S.R., FUHRMANN, J., GOMES, E.S. \& AMARO, R.A. 2017. Description of immatures and mating behavior of Liogenys bidenticeps Moser, 1919 (Coleoptera: Melolonthidae: Melolonthinae). Rev. Bras. Entomol. 61:339-348.

ROMERO-LÓPEZ, A.A. 2016. Comunicación química de coleópteros Melolonthidae distribuidos en México: a una década de distancia. Dugesiana 23(1):59-73

ROMERO-LÓPEZ, A.A., ARZUFFI, R., VALDEZ, J., MORÓN, M.A., CASTREJÓN-GÓMEZ, V. \& VILLALOBOS, F.J. 2004. Sensory organs in the antennae of Phyllophaga obsoleta (Coleoptera: Melolonthidae). Ann. Entomol. Soc. Am. 97(6):1306-1313. https://doi.org/10.1603/00138746(2004)097[1306:SOITAO]2.0.CO;2

ROMERO-LÓPEZ, A.A., MORÓN, M.A. \& VALDEZ, J. 2010. Sexual dimorphism in antennal receptors of Phyllophaga ravida Blanchard (Coleoptera: Scarabaeoidea: Melolonthidae). Neotrop. Entomol. 39:957966.

ROMERO-LÓPEZ, A.A., ARZUFFI, R., VALDEZ, J., SÁNCHEZESPÍNDOLA, E. \& MORÓN, M.A. 2011. Tissues involved in sex pheromone production in Phyllophaga obsoleta (Coleoptera: Scarabaeoidea: Melolonthidae). Ann. Entomol. Soc. Am. 104:960-965. https://doi. org/10.1603/AN10068

RUTHER, J. 2004. Male-biased response of garden chafer, Phyllopertha horticola $\mathrm{L}$., to leaf alcohol and attraction of both sexes to floral plant volatiles. Chemoecology 14:187-192.

SANTOS, V. \& ÁVILA, C.J. 2007. Aspectos bioecológicos de Cyclocephala forsteri Endrodi, 1963 (Coleoptera: Melolonthidae) no estado do Mato Grosso do Sul. Rev. Agric. 82:288-300. 
SANTOS, V. \& ÁVILA, C.J. 2009. Aspectos biológicos e comportamentais de Liogenys suturalis Blanchard (Coleoptera: Melolonthidae) no Mato Grosso do Sul. Neotrop. Entomol. 38(6):734-740.

SONG, Y.Q., DONG, J.F., SUN, H.Z. \& LIU, S.T. 2012. Morphological characteristics of placodea sensilla and coeloconica sensilla on antenna of four chafers. Sichuan J. Zool. 31:905-908. https://doi.org/10.3969/j. issn.1000-7083.2012.06.012

STENSMYR, M.C., LARSSON, M.C., BICE, S., HANSSON, B.S. 2001. Detection of fruit- and flower-emitted volatiles by olfactory receptor neurons in the polyphagous fruit chafer Pachnoda marginata (Coleoptera: Cetoniinae). J. Comp. Phys. A 187:509-519. https://doi.org/10.1007/ s003590100222
SUN, H., GUAN, L., FENG, H., YIN, J., CAO, Y., XI, J. \& LI, K. 2014. Functional characterization of chemosensory proteins in the scarab beetle, Holotrichia oblita Faldermann (Coleoptera: Scarabaeidae). PLoS ONE, 9:e107059. https://doi.org/10.1371/journal.pone.0107059

TADA, S. \& LEAL, W.S. 1997. Localization and morphology of sex pheromone glands in scarab beetles. J. Chem. Ecol. 23(4):903-915.

WANG, G.L. \& SUN, F. 2005. Semiochemicals in phytophagous scarab beetles. Acta Entomol. Sinica, 48:785-791.

YAO, Y.S., YUAN, G.H. \& LUO, M.H. 2004. Observation on the ultrastructures of antennal sensilla in Anomala corpulenta Motschulsky. Acta Agric. Boreali-Sinica 19:96-99. 